\title{
Cultural Specificities of Succession' Failure and Success in the Context of Unlisted Moroccan Family-Owned Businesses
}

\author{
Azzeddine Allioui (Corresponding author) \\ LAREGO Laboratory, ENCG, Cadi Ayyad University - Marrakech \\ Av. Allal El Fassi, Marrakesh 40000, Morocco \\ E-mail : azzeddine.allioui@gmail.com
}

\begin{abstract}
Badr Habba
Chair of Moroccan Family Businesses, ESCA School of Management

LAREGO Laboratory, ENCG, Cadi Ayyad University - Marrakech

Av. Abou Youssef El Kindy, Casablanca 20070, Morocco
\end{abstract}

Taib Berrada El Azizi

Chair of Moroccan Family Businesses, ESCA School of Management

Av. Abou Youssef El Kindy, Casablanca 20070, Morocco

Received: January 18, 2021

doi:10.5296/bms.v12i1.18395 URL: https://doi.org/10.5296/bms. v12i1.18395

\begin{abstract}
The purpose of this research aims to study the relationship between the cultural specificities of the Moroccan context and the success or failure of succession strategies (in terms of planning and process) in the case of Moroccan unlisted family businesses. Our study covered a sample of 20 unlisted Moroccan family businesses, 8 of which are SMEs, 6 are large firms, and 6 are VSEs, through a qualitative research based on semi-structured interviews with the managers of family businesses. Our results explain the influence of Moroccan cultural specificities on the success or failure of the transfer of family businesses. Indeed, these influences essentially manifest themselves in three antecedents: the succession planning that
\end{abstract}


already reflects the intention to pass on the family business to the next generations, either by having a well-prepared plan, or an absence of a succession plan that leaves things to chance; the succession process that is influenced in part by specificities of Moroccan culture by granting privilege to the eldest male in the succession, and in another part this process becomes more rational by giving credit to successors competent to take over the family business in the case of large family businesses; and cultural constraints that are manifested mainly by the taboos surrounding the death of the predecessor and religious principles that similarly explain the different configurations of success or failure of the succession strategy of the family business. An extension of this work could be a multi-factor analysis in future researches.

Keywords: family business, culture, succession plan, succession process, succession failure

\section{Introduction}

The globalization of markets now forces companies, whether large or small, to adapt and transform to meet new situations and requirements. The family business, which is an old and widespread form of organization around the world (Gersick et al., 1997; Durante, 2020) is no excluded from this reality. This type of organization concerns companies whose weight on the economic activity of nations is far from negligible for both developed and developing countries. For example, according to a study by Allouche and Amann (2000), 90\% of companies in the United States are family-owned and contribute between 30 and $60 \%$ of GDP; in Western Europe, between 45 and $65 \%$ of GDP (and employment) is provided by family businesses. However, in the transition from one generation to the next, the family business is particularly vulnerable. Not only is it exposed to the threats that appear in any type of business, but it also faces dangers that are inherent to its family nature.

According to an American study (Cadieux and Lorrain, 2004), only 30\% of family businesses survive their transfer to the second generation and less than $10 \%$ survive such a transfer to the third generation. Moreover, considering the number of years required to prepare for this transfer under good conditions, this gives us an idea of the importance of succession and the problems it can cause. Moreover, in a Western interpretation, business succession can cover different realities: succession to a family member, external takeover by an individual or legal entity, or buyout by one or more employees (Bernhard, Hiepler, and Engel, 2020). These modalities have in common that they are observed in different regions of the world and are based on a process linking two individuals - the predecessor/transferor and the successor/takeover - to ensure the continuity of the business. Strangely, despite the growing importance of francophone research in the field, there are still very few empirical studies devoted to the phenomenon in the Moroccan context, where the issue has a singular resonance.

In fact, this subject is still little studied in developing countries and more particularly in Africa where this form is by far the most widespread. In Morocco, the impetus for the private family enterprise was given in the 1960s. Almost half a century later, these entrepreneurs, 
who have benefited from state support to set up, are now reaching retirement age. Secondly, these social facts, which encompass economic, social, cultural, and political aspects as an integrated system, are nowadays highly topical because of the large number of family businesses created after the period of Moroccan independence in the 1950s. They are mostly so-called first-generation companies, still run by their founders, and will be handed over in the coming years. Naturally, these companies are more in line with a "father to son" rather than "father to peer" succession logic. For it is above all respected the symbolism of the Moroccan entrepreneurs, considered as "bearer of new representations insofar as the fruit of their work represents a heritage to which they are personally attached. Therefore, the succession issue becomes a managerial concern and is part of the medium and long-term objectives of the leaders of family businesses, to ensure the transmission of assets. This socio-economic reality allows us to measure the extent of the phenomenon that interests us and the ultimate challenge of the sustainability and regeneration of family businesses in Morocco, which is in a period of its history where the country is multiplying the avenues of research for development (Morocco's New Development Model 2021).

Purpose of the study

What was the departure of the predecessor like? Is the succession assured? If we cannot speculate on the success of the succession, can we at least describe the phases of the succession in the first instance and reflect on the conditions that might affect it? Despite their centrality for the future of the Moroccan economy, these questions still await academic clarification. Based on this observation, the authors have sought to address the following two questions: How does the succession process (father-child) take place in Moroccan family businesses? and what are the effects of cultural specificities on this process? The objective of this article is to better understand the succession process in Moroccan family businesses. Our central objective consists in positing the existence of cultural specificities in the passage of its basic stages.

To answer this research question, the authors are conducting this research through a qualitative study based on 20 semi-structured interviews with the managers of Moroccan unlisted family businesses.

The first theoretical part of this contribution first clarifies succession planning and processes in family businesses. A second part explains the methodological protocol deployed, which is based on a qualitative study. Finally, in the third part, the authors present and discuss the main findings of the research, before concluding on the contributions, limitations, and possible extensions of this work.

\section{Literature Review}

\subsection{Dilemma Between the Need for Succession Planning and Resistance Factors to Planning}

Planning research is based on one premise: Successful succession planning is all about planning. One of the main contributions of studies on succession planning stems from the 
theoretical model developed by Handler and Kram (1988) in which four major groups of planning resistance factors are identified: individual, interpersonal, organizational, and environmental, all of which are dependent on each other. Based on an exhaustive review of the literature, the authors believe that the main resistance to succession planning is closely linked to the psychological characteristics so peculiar to entrepreneurs. For example, it is likely that the entrepreneurs who have devoted most of their time to their business have never had the opportunity to develop other interests, which ultimately may impact his willingness to withdraw from the day-to-day running of the business. So, to avoid facing new and sometimes distressing realities, the predecessors will do, often unconsciously, everything they can to delay the succession process (Lansberg, 1988; Lu, Kwan, and Ma, 2021).

Moreover, the predecessor would not be solely responsible for the lack of planning. Some resistance may also depend on the quality of the relationship between the two main stakeholders and among other family members, as well as on the internal and external environments of the organization. In this regard, Handler and Kram (1988) argue that in companies where employees are accustomed to change, the process is easier to plan and its evolution more harmonious. For others, the size or sector of activity (Davis and Harveston, 1998; Chan et al., 2020) in which the company operates, as well as the openness of board members, can be sources of resistance (Hugron and Dumas, 1993). Finally, just as the predecessor builds relationships with its staff, so too does it build relationships with its suppliers, customers, and bankers, and depending on how the successor's integration is carried out, they may be resistant (Lansberg, 1988; Lu, Kwan, and Ma, 2021).

Nevertheless, the contribution of all the identified empirical research findings on planning activities remains mixed. On the one hand, those obtained from surveys mailed to large samples of the target population show that, except the age (Davis and Harveston, 1998; Chan et al., 2020) or sex of the predecessor, it is primarily the presence of a competent successor, demonstrating integrity and commitment to the business, that would ensure that formal planning activities are in place on the part of the predecessor (Sharma et al., 2000). On the other hand, when some have focused on understanding the influence of these same planning activities on the success of the succession, factors related to the quality of the relationship between predecessor and successor and among all family members are the most significant (Morris et al., 1997; Takwi, Bate, and Akosso, 2020). The authors argue that the most successful firms are those where the predecessors took the time to choose their successors and did nothing formal until the relationship between the two was to their satisfaction.

For the planning literature, we must admit one thing. While there have been attempts to empirically identify variables that may influence planning activities and succession success, the results still seem to provide little evidence of concrete innovative solutions that can be implemented in the business community.

Indeed, the results of the survey conducted by Morris et al. (1997) show that managers of family-owned firms are more inclined to formalize their planning activities related to the transfer of assets than those related to the transfer of management. Compared to managers of 
non-family firms, the results indicate the extent to which they place less importance on formal activities in preparing their successors and more on their involvement in training their successors.

\subsection{The Transfer of Family Businesses: A Process-Based Approach}

Hugron (1993a) differentiated between two aspects in the succession process, namely succession management and the transfer of assets. Since then, among the transfers discussed in the literature on succession in family-owned businesses, two types of the process can be identified: ownership and management (Hugron, 1993b; Morris et al., 1997; Takwi, Bate, and Akosso, 2020). Although the two types of transfers do not evolve at the same pace, the model of the succession process developed by Hugron and Dumas (1993) emphasizes how essential the two are, together, to ensure the continuity of family businesses. In the proposed model, the two processes each involve four distinct, subsequent, and evolving stages. The transfer of management involves incubation, selection, joint control, and disengagement, while the transfer of ownership involves the initiation of the decision, the decision itself, consultation with experts, and finalization.

Among the literature consulted, and as summarized in Table 1, research on the process can be divided into four main categories of objectives: to know, understand and explain the process; to identify the factors that can ensure the success of the succession; to understand the interest of children in taking over the succession; and finally, to know and understand the psychological dynamics existing among the main actors involved in the process.

Table 1. Research on the succession process

\begin{tabular}{|c|c|c|}
\hline $\mathbf{O b}$ & & \\
\hline $\begin{array}{l}\text { Know, } \\
\text { understand and } \\
\text { explain the } \\
\text { process }\end{array}$ & $\begin{array}{l}\text { Gersick et al., } \\
\text { 1997; Handler, } \\
\text { 1989; Hugron and } \\
\text { Dumas, } \quad 1993 ; \\
\text { Durante, } 2020\end{array}$ & $\begin{array}{l}\text { - Development of numerous models based on life } \\
\text { cycles, role-playing, systemic } \\
\text { - Identification of two main stages: } \\
\text { entrepreneurial and familial } \\
\text { - Identification of two processes: management and } \\
\text { ownership } \\
\text { - Ambiguity in models (business vs. succession) } \\
\text { - } \quad \text { Models with little empirical verification }\end{array}$ \\
\hline $\begin{array}{l}\text { Identify the } \\
\text { success factors } \\
\text { of the process }\end{array}$ & $\begin{array}{l}\text { Morris et al., } \\
\text { 1997; Barach et } \\
\text { al., } 1988 \text {; Takwi, } \\
\text { Bate, and Akosso, } \\
2020\end{array}$ & $\begin{array}{l}\text { - Unclear notions of success } \\
\text { - Most critical: quality of the interpersonal } \\
\text { relationship between predecessor/successor and } \\
\text { family members }\end{array}$ \\
\hline $\begin{array}{l}\text { Understand the } \\
\text { interest of } \\
\text { successors to } \\
\text { take over the }\end{array}$ & $\begin{array}{ll}\text { Barach } & \text { et al., } \\
\text { 1988; } & \text { Handler, } \\
\text { 1989; } & \text { Stravou, } \\
1999 ; & \\
\end{array}$ & $\begin{array}{l}\text { - The credibility of the successor } \\
\text { - Need to prove their abilities } \\
\text { - Main limitation: Sample of students who have } \\
\text { not yet joined the company. }\end{array}$ \\
\hline
\end{tabular}


business

\begin{tabular}{llrl}
\hline Understanding & Davis & and & - Understanding the influence of family dynamics \\
psychological & Harveston, 1999; - Assimilation of certain unavoidable notions, \\
dynamics & Dumas, 1989; such as equity, patterns, triangular relations, the \\
& Friedman, 1991; mourning process, etc. \\
& Pailot, 2000; - Few avenues for concrete solutions \\
& Chan et al., 2020
\end{tabular}

Source: Elaboration by the authors

\subsubsection{Research on Understanding the Process}

The authors who were interested in knowing, understanding, and explaining the process did so from different perspectives. While some have used a life-cycle approach (Gersick et al., 1997; Durante, 2020), others have taken a more microscopic approach (Handler, 1989; Hugron and Dumas, 1993; $\mathrm{Ng}$ et al., 2021). This has resulted in the development of two main types of models. The first describes the evolution of the firm in general, while the others describe more specifically the evolution and involvement of the two main stakeholder groups, the predecessor and the successor.

The first contribution of this research lies in the fact that the authors who have developed models on the succession process and the evolution of family businesses agree on the existence of two important stages. The first is mainly the one where the owner-manager is the sole master on board. The second begins when the owner-manager shares powers and responsibilities with at least one family member to ensure the continuity of the business.

The second contribution of the results of this type of research is that they make it possible to know, understand, and explain the succession process as a whole. Developed primarily using case study strategies, the models developed, which include between 3 and 7 phases (Hugron and Dumas, 1993; Gersick et al., 1997), inform us, each in their own way, of the steps involved in the process. However, based on the life-cycle models of organizations and individuals, they tend to take a linear reading of the process and assume that the company will become a large enterprise, with all that this entails.

Handler (1989), with his role-playing model, describes the process through the different roles that the predecessor and successor will take on in turn. From the author's point of view during the succession process, the predecessor subsequently assumes four roles: sole operator, sovereign, supervisor, and consultant, while the successor must also successively assume the roles of an assistant, manager, and leader. As the dynamics of the various transfers inherent in the succession process become more dynamic, the last respective roles of consultant for the predecessor and leader for the successor can only be assumed once there is a complete transfer of know-how, responsibility, leadership, and authority.

According to Handler (1994), it is common to observe a blockage in the evolution of the succession process in the second or third phase. In such cases, the successor would never 
fully assume the leadership role of the disengagement phase since some of the transfers inherent in that phase would never be fully completed as long as the predecessor was able to assume them (Hugron and Dumas, 1993). This brings us back to the resistance factors discussed earlier. As with planning, the main reasons why the predecessor would block the process, often unconsciously, would stem from his ability to let go, his ability to detach, and accept losing control over decisions about his firm. Thus, it is possible to make a link between the psychological and behavioral characteristics of the predecessor and the transfer of his emotional needs to his business and to assume that one of the major obstacles to succession planning and completion stems from his difficulty in letting go.

\subsubsection{Research on Success Factors}

In the literature consulted on the success factors of succession, the notion of success in itself is confusing. For example, while success is defined as the effective transfer of ownership and management of the business to the next generation, others measure it in terms of criteria associated with business performance (Morris et al., 1997, Allioui, Habba, and El Azizi, 2020) or the emergence of conflicts between family members.

For the successor's career plan, apart from the consensus that the successor must gain credibility with the members of the organization (Barach et al., 1988), there is disagreement about when and how the successor should join the family business. Also, one of the success factors is the rapid integration of children into positions of responsibility, while for Barach et al. (1988), this would depend more on the experience acquired by the successor in other spheres of activity and other organizations before formally joining the family business. On this subject, the results of a survey conducted by Morris et al. (1997) among about 100 successful family business managers show that, in their case, the successors were well prepared, both in terms of their academic training and the diversity of work experience acquired within the family business. The success of the successor's integration would therefore depend on a much more complex set of factors than the timing of his integration into the family business.

Finally, as with planning, it appears that the most critical success factor is the quality of the relationship among all family members (Morris et al., 1997; Takwi, Bate, and Akosso, 2020). However, these success factors have been measured primarily by variables such as trust, communication, shared values, affability, honesty, and mutual respect, all of which are emotional and therefore, by definition, difficult to measure and easily questioned.

\subsubsection{Research on the Perception of the Successor}

Studies on the perception of the successor focus on the interest of potential successors in joining the family business and how they felt after having carried out their project. The results of these studies show that it can take between two and five years before successors can be considered credible by their peers (Barach et al., 1988). Feeling that they are being watched by everyone, they say that they have very little room for error during their entire period of integration into the family business, regardless of their position. 
For their part, the results of the study by Stravou (1999) of future successors indicate that the only obstacle to their definitive integration into the family business comes from their need to prove to themselves and others their ability to be autonomous. All of them indicate that the decision to join the family business is theirs and that under no circumstances are they under pressure from their parents. Nor would the difficulty in letting go of predecessors be a deterrent. On the contrary, the more resistance there would be from the predecessor, the more interesting challenge would be for the successor (Stravou, 1999). However, an important limitation arising from the sample requires caution in interpreting these same results. While both researchers surveyed university students who are considered future heirs who have not yet joined the family business as official successors, when compared with the results of the survey of successors in place for the past few years conducted by Morris et al. (1997), the picture differs in that $61 \%$ said they were explicitly encouraged by their predecessors to take over the business.

\subsubsection{Research on Psychological Aspects of Succession}

Essential to the desire to understand the nature of the conflicts that can exist in the context of family businesses, research on the psychological aspects of succession is mainly concerned with the actors, the interpersonal relationships between predecessors and successors, and family dynamics.

Dumas (1989) research shows how important are the psychological aspects and how different the relationship is when it is between a father and his daughter. For example, just as few founders foresee the possibility of leaving a decision-making position to their daughters, their daughters do not fully appreciate themselves in their new responsibilities. Often taking up their new positions by accident, they tend to want to protect their fathers. For this reason, they say they have relationship problems with their fathers' right-hand men and with their mothers, for whom they are likely to take their place.

Here, the authors cannot ignore the work of Pailot (2000). Strongly inspired by the Freudian model of the mourning process, it is following a unique in-depth case study that the author proposes the separation process model to explain the psychological process of the entrepreneurs who have to separate from the company they were the head of for several years. Although difficult to generalize, the model presented by the author indicates how long it can take an entrepreneur to separate from his business. In this case, it took four years of questioning, doubt, resistance, and disorganization before a more positive attitude to the inevitable change faced by the entrepreneur emerged.

Finally, other studies allow the integration of concepts that are essential to the understanding of the succession process in family businesses. Among other things, with the main objective of presenting an analytical framework for understanding the dynamics existing among all sibling members, Friedman (1991) emphasizes the extent to which parents are responsible for the quality of the relationship that may exist among them. For the author, often despite themselves, parents compare their children in the same way as they teach them their models 
of equity or conflict resolution often transposed in a business context. For his part, following a longitudinal case study of three family businesses.

\section{Methodology}

Despite the existing francophone literature on business transfers, the authors lacked interest in the realities of this process in the Moroccan context. This qualitative research follows an abductive mode of reasoning for two main reasons. First, it is an exploratory approach, aimed at improving the understanding of complex phenomena and the specificity of their object (Huberman and Miles, 1991). The aim here is to reinforce our central proposition, which questions the cultural specificities of the conduct of transmissions of Moroccan family businesses. Secondly, we are not in a context that is devoid of knowledge, since we already have conceptual and theoretical support that could help us, as in the case of the Cadieux process (2004). However, most of the theoretical corpus on transmission has been built up from Western approaches. By proceeding by abduction, the authors try to approach the phenomenon to be studied with a minimum of preconceived ideas to let the field speak; that is, by trying to make ourselves as receptive as possible to the reality that emerges from the observations.

Indeed, studying the inheritance process from a Moroccan perspective requires a contextual approach to the phenomenon. Nevertheless, access to the field has proved difficult, because in Morocco, as elsewhere in Africa, there are no accurate official statistics on business transmissions.

The characteristics of the sample are presented in (Table 2). Of the 20 firms in our sample, six are large firms, eight are SMEs, and six are VSEs. Without claiming to be exhaustive, the theoretical representation of the sample is ensured by the diversity of cases in terms of the category of firms and sector of activity, which makes it possible to account for the complexity of the phenomenon studied.

Table 2. Our Qualitative Study Sample

\begin{tabular}{|c|c|c|c|c|c|}
\hline $\begin{array}{l}\text { Code } \\
\text { Company }\end{array}$ & Size & $\begin{array}{c}\text { Year of } \\
\text { creation }\end{array}$ & $\begin{array}{l}\text { Number of } \\
\text { generations }\end{array}$ & City & Sector \\
\hline FB no. 1 & SME & 1994 & 3 generations & Casablanca & Wholesale trade \\
\hline FB no. 2 & SME & 1999 & 2 generations & Marrakech & Remediation \\
\hline FB no. 3 & SME & 2003 & 2 generations & $\begin{array}{l}\text { EL } \\
\text { HAOUZ }\end{array}$ & Construction \\
\hline FB no. 4 & VSE & 2002 & 2 generations & Casablanca & $\begin{array}{l}\text { Miscellaneous } \\
\text { printing }\end{array}$ \\
\hline FB no. 5 & VSE & 1993 & 2 generations & Marrakech & Tourist agency \\
\hline FB no. 6 & SME & 1994 & 2 generations & Marrakech & Construction \\
\hline FB no. 7 & SME & 1958 & 2 generations & Marrakech & Printing \\
\hline FB no. 8 & VSE & 1990 & 3 generations & Marrakech & Carpentry \\
\hline
\end{tabular}




\begin{tabular}{llllll}
\hline FB no. 9 & SME & 1974 & 2 generations & Marrakech & Private education \\
\hline FB no. 10 & VSE & 2006 & 2 generations & Azilal & Tourism \\
\hline FB no. 11 & Large & 1965 & 2 generations & Casablanca & Industry \\
\hline FB no. 12 & VSE & 2000 & 2 generations & Marrakech & Agriculture \\
\hline FB no. 13 & VSE & 1996 & 2 generations & Agadir & Tourism \\
\hline FB no. 14 & SME & 1970 & 4 generations & Marrakech & Distribution CHR \\
\hline FB no. 15 & Large & 1979 & 3 generations & Casablanca & Industry \\
\hline FB no. 16 & Large & 1978 & 2 generations & Marrakech & Industry \\
\hline FB no. 17 & Large & 1976 & 2 generations & Marrakech & Construction \\
\hline FB no. 18 & Large & 1992 & 2 generations & Marrakech & Textille \\
\hline FB no. 19 & Large & 1990 & 2 generations & Agadir & Tourism \\
\hline FB no. 20 & SME & 2012 & 2 generations & Marrakech & Distribution CHR \\
\hline
\end{tabular}

We used a "pre-structured" interview guide in the form of open-ended questions based on predefined themes: the identity of the predecessor, the successor's background, the history of the company, and the succession process itself.

A manual thematic content analysis was conducted, following the methodology of Huberman and Miles (1991) allowing the classification of data into classes. In addition to a horizontal (inter-interview) analysis in the form of summary sheets, the raw data were also subjected to a vertical (intra-interview) analysis using thematic coding, based on the process approach developed by Cadieux (2004): transmission planning, choice of successor, integration strategy, and disengagement of the successor. This method of analysis allowed us to assess the transmission process at work in Moroccan family firms and to raise the cultural specificities associated with it.

\section{Empirical Results Analysis and Discussions}

The results of the analysis of the twenty cases are presented and discussed around four points that echo the processual approach defined by Cadieux (2004). The Moroccan context reveals the singularities that may exist primarily at the level of the preparation of the transmission to the following generations, then in the course of the succession process itself, during the stages of initiation (choice of the successor), integration (strategies of entry into the successor's firm) and those concerning both transition and disengagement (the predecessor's exit condition).

\subsection{Preparing for Transmission to the Next Generations in the Moroccan Context}

As in the review of the literature on the subject (Cadieux and Lorrain, 2004), one of the first difficulties encountered is the preparation and planning of transmission to the following generations. The interviews that authors conducted in Morocco mostly follow this line of thought. The results reveal that managers do not think about the transfer of their firm. Nevertheless, they allow us to distinguish different succession planning scenarios related to the size of the family firm (VSE, SME, large). VSEs and a few SMEs do not have a succession plan. "In most cases, the founder is too poorly endowed with cultural capital and managerial 
knowledge to consider possible planning. The successor only takes over the head of the small family business if the predecessor is completely unavailable, due to sudden illness or death. "(CEO of the FB no. 4). These are the dramatic circumstances that brutally propel the successor at the head of the company, confirming several observations on the dangers of chronic unpreparedness. "The patriarchs think they are irreplaceable and postpone the moment of handing over the reins, even if it means disappearing without leaving a will, but also and above all without having entrusted the responsibilities of the company to their successors, so that the succession takes place in the most complete improvisation, sometimes with fatal consequences for the family business. "(CEO of the FB no. 8).

It can be observed that some family-owned SMEs (FB no. 3, FB no. 14, and FB no. 20) follow logic very close to that of family-owned VSEs. These are often small enterprises that have gradually moved from VSEs to SMEs, but in which no succession plan is envisaged, except for small family groups (FB no. 1, FB no. 2, and FB no. 9), which have more advanced planning procedures. The latter family-owned SMEs consider it strategic to set up a schedule for the devolution of power to the new management generation. In these organizations, it is clear that the potential successor is at the outset moving closer to a more Western conception of transmission. This is based less on content than on the act of transmitting: what is transmitted is ultimately transmission itself, as a relational form and guiding value. The choice of renouncing the implementation of one's succession thus appears even more difficult in a country like Morocco, because of the polygamy regime. In the traditional imagination, it has often been admitted that "the increase in the number of an entrepreneur's wives and children often accompanies his professional success, and is understood as a legitimately accepted means of emphasizing it and tuning it to the precepts of the "Quran", sometimes distancing popular mistrust of wealth. "(CEO of the FB no. 11). By extension, if the issue of succession has not been resolved, rivalries between wives on the one hand and siblings on the other can lead to acute conflicts that can threaten the continuity of the business in polygamous families, especially in Morocco where the superimposition of positive law and Muslim law can complicate the issue of succession and inheritance. The leader of the FB no. 14 illustrates such a situation with a long and violent conflict between the two heir brothers over the control of the family business. After several years of unsuccessful mediation by relatives and family members, the case will end up in court. The father's level of control thus seems to considerably reduce the chances of arriving, in the event of death or illness, at an equitable sharing of ownership and leadership, i.e. a favorable situation of co-leadership (Deschamps and Cisneros, 2012).

In many African countries, the transmission of assets from one generation to the next sometimes encounters less opposition between heirs, than the difficulty for the heirs to meet all the social, political, or relational conditions without which these assets lose their productive value (Bocco, 2009). 


\subsection{The Succession Process in Moroccan Family Businesses}

A crucial decision at the initiation stage concerns the choice of the successor, i.e., the future leader, who will, in most cases, also be the new owner (Missonier, and Gundolf, 2017). Moroccan family firms face this challenge (Allioui and Habba, 2019 ; Allioui, Habba, and El Azizi, 2021). The cases identify a possible hierarchy of selection logic, each of which expresses particular cultural resonances.

Most Moroccan families still follow the traditional patriarchal model, in which the transmission of the family business is in the male line. This hierarchical order, corresponding to the anthropology of kinship, stems from the idea that initiatory elders know the beginning of stories when cadets only know the end. The choice of the male elder to replace the leading father remains the dominant norm, as many cases in our study show (FBs no. 5, 6, 7, 11, 12, and 13). This is in line with a widespread pattern already noted by Lansberg (1999) in his work on new generations of successors. This mechanical model of transmission requires that the eldest child be considered as the natural successor of the father in the family, as he is likely to have more experience and wisdom. In this sense, he benefits from a form of law that makes the other children be obliged by him subordination and respect. He is therefore called upon to take over the family business to develop it, with the mission of passing on his knowledge to the younger ones. Generally speaking, his destiny seems to be written in advance, even if the economic outlook is not very bright and access to strong responsibilities may seem remote. While it is unlikely that the descendants will openly contest the reins of the family business, with rare exceptions, present in our sample, the eldest son may break with tradition by renouncing the privilege of succession to embark on another career, thus opening the way for succession to the cadets (FB no. 19). On the whole, however, this mode of selection locks women into the roles of wife and mother, due to a social environment (traditions) that weighs and slows down the promotion of their status in the family to some extent.

If the transmission by filiation is based on the principle of conservation (inheritance), it also cohabits with the hereditary transmission of the craft. As illustrated in FB no. 15 and 16, it is a means of avoiding the risk of bankruptcy linked to the capacity for resistance, or even aggression, held by the lineage group when the management of a cadet's affairs relies primarily on economic calculations based on family altruism (Bocco, 2009). Transmission by marriage is also part of heredity, with regard to the principle of the alliance, which invites us not to underestimate the role of nephews and sons-in-law in the perpetuation of family businesses. Two main causes seem to maintain this mode of selection, with first of all a desire to diversify risks and ensure the perpetuation of the business. This selection logic then echoes the nuclearization of Moroccan families and the rampant individualization of Arab-African companies, especially for managers who see it as a way to increase the value of family assets.

Besides, in the third mode of selection, the social elder is implemented, with criteria that are completely independent of the birth rank and gender of the successor. The choice of the heir is based on demonstrations of merit, skills, personality, management ability, and constant commitment to the family's management. This choice is anchored in the theory of agency and 
skills. It is above all human capital in its component that is valued, opening up the selection process to women in the family who were not previously considered potential successors, even if they worked in the family business. It now seems possible for the latter to find themselves in direct competition with their brothers to run the family business (FB no. 10 and 13), especially when the family business has reached a stage in its development and formalization. This form of selection confirms the growing influence of women recently observed in family business transfers worldwide.

In another vein of ideas, in family businesses, it is recognized that the initiation continues until the so-called integration phase (Koffi and Lorrain, 2011). The results confirm the two main strategies for the entry of successors into the family business, with a cultural particularity. Indeed, contrary to small and medium family firms that essentially favor a gradual entry of the successor (thus favoring an empirical training), large family firms seem to choose a deferred entry to offer the heirs academic training and professional experiences, outside the firm and the family. The cases studied nevertheless reveal specific hybridizations in the practices of integrating successors through the acquisition of empirical and academic knowledge.

Based on the businesses examined, all of the heirs (except those of FBs no. 11, 15, and 19) learned the business and the nuts and bolts of the small business on the job, alongside their fathers, before taking over the business, very often unexpectedly, following their father's illness or death. Limited in knowledge and managerial methods, these successors have only known the family business (Bozer, Levin, and Santora, 2017) which they sometimes joined at a very young age, in rather traditional sectors. Moreover, these entrepreneurs have been able to compensate for this lack of discursive skills with practical skills based on rigor in the management of their business (positive cultural representation). By the force of difference, they have been able to mobilize skills and social intelligence not taught in management manuals. Better still, this experience on the margins was for them an opportunity to give meaning to the action of undertaking or leading, and to develop a culture of boldness and risk. They were able to build their career as successors by going back and forth between the past and the present.

\subsection{The Cultural Specificities of Succession in Morocco}

The research highlights cultural specificities, following in the footsteps of several works that have begun to question more strongly the cultural singularities of entrepreneurial practices (El Azizi, Habba, and Allioui, 2020), and business transmission in particular (Bah et al., 2017). In this sense, the analysis of empirical cases highlights that Moroccan family firms do not form a homogeneous block, whereas the majority of the literature on Arab-African firms tends to study them as if they were all similar and assimilated.

More precisely, the authors observe a sequencing that departs, at least partially, from the Western reference frame, particularly in its relation to the phases of disengagement. The taboo on death pushes back any questioning on the part of the predecessors. Indeed, Moroccan society exalts life, valuing the elderly and making the dying safe, contrary to the mores of 
Western societies (Walter, 2012). The prestige of the elders makes the Moroccan leaders extend their reign as long as they wish. In fact, a major breaking point lies in the conditions of exit of the predecessor, necessarily incomplete in the case of the large family firms in our sample (partial disengagement), and simply inconceivable in the context of family VSEs and SMEs. This configuration illustrates a Moroccan singularity that condemns the new generations to live an improvised or too late succession, following the death and/or disease of the founder, in a climate of family dissension that can lead to the dispersion of assets and the liquidation of the family business.

Fatally, the shock of the father's death or incapacity brings a second risk that is just as serious and traumatic for the family: the disappearance of the business (Morris et al., 1997), the sole source of family income for daily subsistence. Also, since succession is a life constraint, the authors find to varying degrees the sources of resistance highlighted by the work of Handler and Kram (1988), namely the psychological brakes of the predecessor in preparing his transmission, the reluctance to withdraw, conflicts between heirs (accentuated in the case where the family is extended), or even the refusal to succeed the eternal father. Similarly, the predominantly patriarchal and communal Moroccan culture (duty of solidarity) and the cultural beliefs shared in the country (religion) have a real influence on the conduct of the transmission of Moroccan family businesses.

\subsection{Research Model From our Qualitative Study}

The following figure summarizes our findings on the preparation and succession process for unlisted Moroccan family businesses:

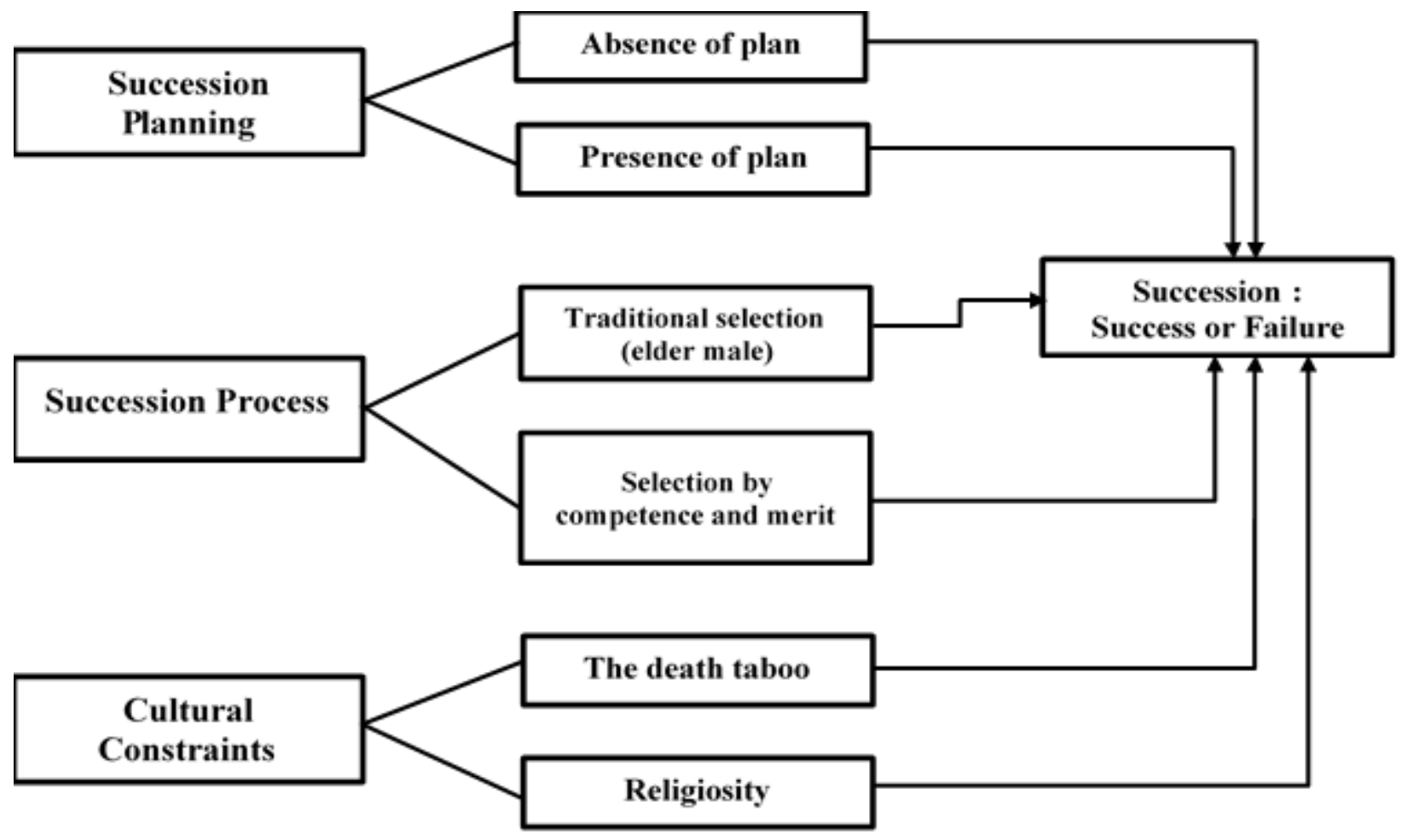

Figure 1. The research model of our qualitative study 
Our results explain that the success or the failure of the succession stage of the Moroccan unlisted family business is essentially based on three antecedents: 1) the succession planning that already reflects the intention to pass on the family business to the next generations, either by having a well-prepared plan, or an absence of a succession plan that leaves things to chance; 2) the succession process that is influenced in itself in part by specificities of the Moroccan culture by granting privilege to the eldest male during the succession, and in another part, this process becomes more rational by giving merit to successors who are competent to take over the family business in the case of the large firms; and (3) cultural constraints that are manifested mainly by the taboos surrounding the death of the predecessor and religious principles that similarly explain the different configurations of success or failure of the succession strategy of the family business.

\section{Conclusion}

Whether it concerns planning activities or the succession process as such, the results of the empirical studies are convergent. The continuity of family businesses depends largely on the willingness and ability of the predecessors to establish their succession and to disengage from the day-to-day business of the companies they masterfully managed for several years. Succession in family businesses is indeed an issue that presents invaluable challenges for researchers, but only if they recognize the prescriptive and exploratory nature of the existing foundations and then agree to question them, of course, with the sole aim of improving our understanding of them and thus proposing solutions that are increasingly appropriate and relevant to those we should consider as the primary stakeholders, i.e., the business people who have high expectations of the academic community.

Within this framework, various factors, both human and economic, can lead to transmission failure. Transmission often rhymes with tension. Tensions are frequent but can, in some cases, be avoided. The failure of the transmission can lead to the bankruptcy or sale of the business, and thus its exit from the family, or can cause irreversible tensions. To avoid these failures and facilitate the process, several tools can be put in place, such as a succession plan and/or a shareholder agreement. To preserve the family's name of the company, a family charter and/or a family council can also be created. The transfer of a family business requires above all psychology, patience, and kindness to reconcile the interests of the family and the business.

The twenty family businesses analyzed, show that the reality of the phenomenon studied calls for a contextualized re-reading of the process. In this respect, our results clearly show the existence of specificities in the way succession is approached in Morocco compared to other regions of the Western world (Canada, Europe in particular). Thus, our theoretical contribution lies in proposing a model that can explain the success or failure of succession, in relation to Moroccan cultural influences. 


\section{Recommendations}

On a theoretical level, beyond the limits inherent in all qualitative research, this contribution appears stimulating on several levels.

First, an extension of this work could be to replicate this study on a larger sample of Moroccan firms. In this case, a multi-factor analysis would be useful. Triangulation of stakeholders' views would enrich the understanding of the phenomenon under study.

Also, parameters such as gender may be likely to influence inheritance practices (Allioui, Habba, and El Azizi, 2021), as in the work of Koffi and Lorrain (2011), which underlines the particularity of female inheritance. In this regard, it would be relevant to take greater account of women's successors, especially since half of African SMEs are now owned and run by women and merit-based selection and integration are gaining ground.

Besides, a complementary line of research could lead to studying the impact of the arrival at the head of family businesses of a new generation of entrepreneurs, often better trained than previous generations in managerial practices, both abroad and locally. This new generation is likely to profoundly transform Morocco's business world in the long term.

\section{References}

Allioui, A., \& Habba, B. (2019). Les effets des objectifs non financiers sur l'évaluation des entreprises familiales marocaines: une approche exploratoire. Moroccan Journal of Entrepreneurship, Innovation and Management, 4(1), 29-40. https://doi.org/10.48396/IMIST.PRSM/mjeim-v4i1.16002

Allioui, A., Habba, B., \& El Azizi, T. B. (2021). Women's Leadership and Pragmatism Incidences on Performance of Listed Family-Owned Firms in the Cultural Context of Arab Countries. International Journal of Financial Research, 12(3), Special Issue, May, 2021. https://doi.org/10.5430/ijfr.v12n3p251

Allioui, A., Habba, B., \& El Azizi, T. B. (2021). Financial Health of Moroccan Unlisted Family Businesses: Explanation By Emotional And Social Dynamics. Revue Economie, Gestion et Société, 1(29). https://doi.org/10.48382/IMIST.PRSM/regs-v1i29.25154

Allioui, A., Habba, B., \& El Azizi, T. B. (2020). Transgenerational Succession'Effects on Financial Performance of Listed Family Firms in the Arab Countries. European Scientific Journal, 16(25), 125. https://dx.doi.org/10.19044/esj.2020.v16n25p125

Allouche, J., \& Amann, B. (2000). L'entreprise familiale: un état de l'art. Finance Contrôle Stratégie, 3(1), 33-79.

Bah, T., Boussaguet, S., De Freyman, J., \& Ndione, L. (2017). La transmission des entreprises familiales au Sénégal: quelles spécificités culturelles?. Revue internationale PME, 30(3-4), 127-161. https://doi.org/10.7202/1042663ar 
Barach, J. A., Gantisky, J., Ourson, J. A., \& Doochin, B. A. (1988). Entry Of The Next Génération: Stratégie) Challenge For Family Business. Journal 01 Small Business Management, 3, 12.

Bernhard, F., Hiepler, M., \& Engel, F. X. (2020). Family Business Sustainability: The Intergenerational Transfer of Social Capital and Network Contacts. In Sustainable Innovation, pp. 101-132. Palgrave Pivot, Cham. https://doi.org/10.1007/978-3-030-30421-8_9

Bocco, B. S. (2009). Les dimensions socioculturelles du comportement commercial des Petites Entreprises en Afrique. Market Management, 9(1), 93-114. https://doi.org/10.3917/mama.053.0093

Bozer, G., Levin, L., \& Santora, J. C. (2017). Succession in family business: multi-source perspectives. Journal of Small Business and Enterprise Development. https://doi.org/10.1108/JSBED-10-2016-0163

Cadieux, L. (2004). La succession dans les entreprises familiales: une étude de cas sur le processus de désengagement du prédécesseur (Doctoral dissertation, Université du Québec à Trois-Rivières).

Cadieux, L., \& Lorrain, J. (2004). Et si assurer sa relève dépendait aussi de la manière dont les prédécesseurs réussissent à se désengager?. Gestion, 29(3), 120-128. https://doi.org/10.3917/riges.293.0120

Chan, F., Jalandoni, D., Sayarot, C. A., Uy, M., Daradar, D., \& Aure, P. (2020). A Family Affair: A Quantitative Analysis of Third-Generation Successors' Intentions to Continue the Family Business. Organizations and Markets in Emerging Economies, 11(2), 462-481. https://doi.org/10.15388/omee.2020.11.43

Davis, P. S., \& Harveston, P. D. (1998). The influence of family on the family business succession process: A multi-generational perspective. Entrepreneurship theory and practice, 22(3), 31-53. https://doi.org/10.1177/104225879802200302

Davis, P. S., \& Harveston, P. D. (1999). In the founder's shadow: Conflict in the family firm. Family Business Review, 12(4), 311-323. https://doi.org/10.1111/j.1741-6248.1999.00311.x

Deschamps, B., \& Cisneros, L. F. (2012). Co-leadership en succession familiale: un partage à définir. Revue Entreprendre \& Innover, 14(2), 49-57. https://doi.org/10.3917/entin.014.0049

Dumas, C. (1989). Understanding of father-daughter and father-son dyads in family-owned businesses. Family Business Review, 2(1), 31-46. https://doi.org/10.1111/j.1741-6248.1989.00031.x

Durante Alonso, A. (2020). Dirección y sucesión en las empresas familiares.

El Azizi, T. B., Habba, B., \& Allioui, A. (2020). Contribution à l'étude de l'impact des contraintes financières sur l'investissement des entreprises familiales dans le Monde Arabe. 
Revue Management Innovation, (2), 31-54. Retrieved from https://www.cairn.info/revue-management-et-innovation-2020-2-page-31.htm

Friedman, S. D. (1991). Sibling relationships and intergenerational succession in family firms. Family Business Review, 4(1), 3-20. https://doi.org/10.1111/j.1741-6248.1991.00003.x

Gersick, K. E., Davis, J. A., Hampton, M., \& Lansberg, 1. (1997). Generation to generation: life cycles of the family business.

Handler, W. C. (1989). Managing the family firm succession process: The next-generation family member's experience (Doctoral dissertation, Boston University).

Handler, W. C. (1994). Succession in family business: A review of the research. Family business review, 7(2), 133-157. https://doi.org/10.1111/j.1741-6248.1994.00133.x

Handler, W. C., \& Kram, K. E. (1988). Succession in family firms: The problem of resistance. Family business review, 1(4), 361-381. https://doi.org/10.1111/j.1741-6248.1988.00361.x

Huberman, A. M., \& Miles, M. B. (1991). Analyse des données qualitatives: recueil de nouvelles méthodes. Éditions du Renouveau pédagogique; De Boeck,.

Hugron, P. (1993). Succession et survie des entreprises familiales au Québec(étude exploratoire de 34 cas de succession, 1983). Cahier de recherche- Ecole des hautes études commerciales. Groupe de recherche sur les entreprises familiales.

Hugron, P. (1993b), L'entrepreneur et la succession d'entreprise : analyse de douze processus (1985), Groupe de recherche sur les entreprises familiales, Cahier de recherche no.GREF-93-03, Hautes Études Commerciales.

Hugron, P., \& Dumas, C. (1993). Modélisation du processus de succession des entreprises familiales québécoises. Cahier de recherche- Ecole des hautes études commerciales. Groupe de recherche sur les entreprises familiales.

Koffi, V., \& Lorrain, J. (2011). Comment des femmes à la tête de PME réussissent-elles leur succession?. Gestion, 36(1), 35-40. https://doi.org/10.3917/riges.361.0035

Lansberg, I. (1988). The Succession Conspiracy. In Family Business Sourcebook, Omnigraphics, inc. (1991), 98-119. https://doi.org/10.1111/j.1741-6248.1988.00119.x

Lansberg, I. (1999). Succeeding generations: Realizing the dream of families in business. Harvard Business Review Press.

Lu, F., Kwan, H. K., \& Ma, B. (2021). Carry the past into the future: the effects of CEO temporal focus on succession planning in family firms. Asia Pacific Journal of Management, 1-42. https://doi.org/10.1007/s10490-020-09748-4

Missonier, A., \& Gundolf, K. (2017). L'entreprise familiale: état et perspectives de la recherche francophone. Finance Contrôle Stratégie, (20-2). https://doi.org/10.4000/fcs.1933 


\section{Macrothink}

Morris, M.-H., Williams, R.-O., Allen, J.-A. \& Avila, R.-A. (1997). Correlates of Success in Family Business in Transitions, Journal of Business Venturing, 12(5), 385-401. https://doi.org/10.1016/S0883-9026(97)00010-4

Pailot, P. (2000). De la difficulté de l'entrepreneur à quitter son entreprise. Histoire d'entreprendre. Les réalités de l'entrepreneuriat, Editions EMS, 275-286.

Sharma, P., Chua, J. H., \& Chrisman, J. J. (2000). Perceptions about the extent of succession planning in Canadian family firms. Canadian Journal of Administrative Sciences/Revue canadienne des sciences de l'administration, 17(3), 233-244. https://doi.org/10.1111/j.1936-4490.2000.tb00223.x

Stravou, E.-T. (1999), « Succession in Family Business: Exploring the Effects of Demographic Factors on Offsprings Intentions to Join and Take Over the Business », Journal of Small Business Management, 37(3), 43-61.

Takwi, F. M., Bate, B. E., \& Akosso, V. (2020). Family Businesses Management and Succession: A Meta-Analysis. American Journal of Operations Management and Information Systems, 5(3), 56-61. https://doi.org/10.11648/j.ajomis.20200503.14

Walter, T. (2012). Why different countries manage death differently: a comparative analysis of modern urban societies 1. The British journal of sociology, 63(1), 123-145. https://doi.org/10.1111/j.1468-4446.2011.01396.x

\section{Copyright}

Copyright for this article is retained by the author(s), with first publication rights granted to the journal.

This is an open-access article distributed under the terms and conditions of the Creative Commons Attribution license (http://creativecommons.org/licenses/by/4.0/). 